\title{
IRAN-US RELATIONS AFTER THE DEATH OF QASSEM SOLEIMANI
}

\author{
Firmanda Taufiq ${ }^{1}$ \\ Ayu Maulida Alkholid ${ }^{2}$ \\ ${ }^{1,2}$ Kajian Timur Tengah Pascasarjana UIN Sunan Kalijaga Yogyakarta \\ 1Email: firmandataufiq@gmail.com
}

\begin{abstract}
Iran-United States relations have up and down. Some sharp diplomatic statements made by the US president, Donald Trump, as well as the president of Iran, Ayatullah Khomeini. In fact, the sanctions that must be accepted by the US against Iran are embargo sanctions. This article aims to analyze how the future relations between Iran and the United States. Cooperation between the two countries has a history that dates back to the Cold War. Relations between these two countries based on a variety of interests, including economic, political, military, ideological, and security considerations. The theory used in this research is balance of power theory. The US has major interest in the Middle East and Iran is a rival of the US in achieving that interest. Nevertheless, many US foreign policies are caused tension between the two countries. Conversely, Iran has considerable economic importance, but the role of the Iran government elite also has a significant influence in the determination of their foreign policy. The findings in this study, despite challenges and complicated processes, the US and Iran are eternal rivals in the fusion of power and political influence in the Middle East, and relations between both will continue to fluctuate .
\end{abstract}

Keywords: Diplomacy, Iran, United States, Qassem Soleimani.

$$
\begin{aligned}
& \text { ملخص } \\
& \text { العلاقة بين إيران والولايات الأمريكية المتحدة في حالة الارتفاع والانخفاض على خلفية تبادل التصريحات السياسية }
\end{aligned}
$$

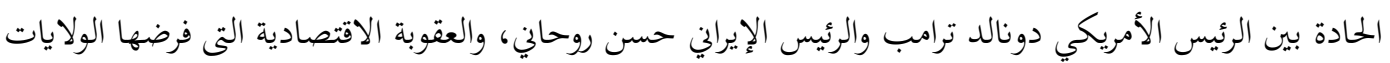

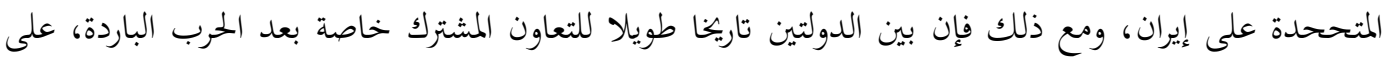

$$
\begin{aligned}
& \text { أساس مصالح اقتصادية وسياسية وعسكرية وأيديولوجية. يهدف هذا البحث إلى رصد مستقبل العلاقة السياسية }
\end{aligned}
$$

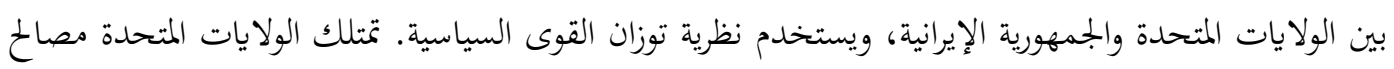

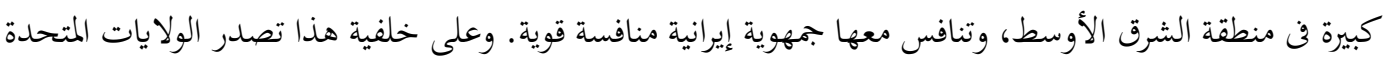

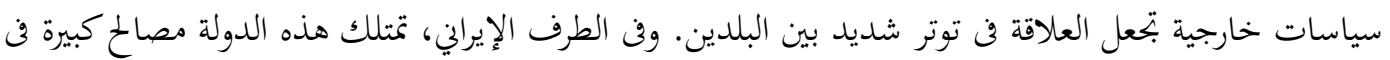

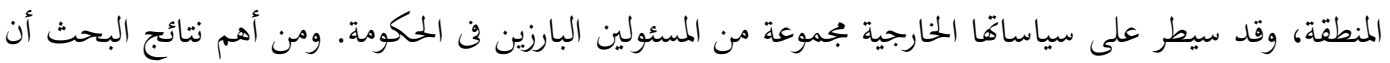

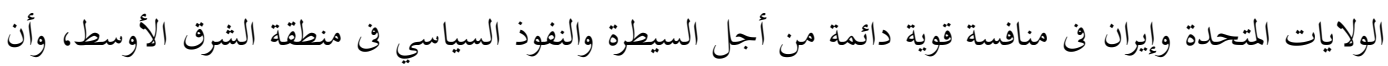

$$
\begin{aligned}
& \text { العلاقة بينهما فن سجال بين بين الكر والفر. } \\
& \text { الكلمات المفتاحية: الدبلوماسية، إيران، الولايات المتحدة، قاسم سليمان. }
\end{aligned}
$$

\section{A. Pendahuluan}


Mossadegh, pada Agustus 1953 (Simbar, 2006). Amerika Serikat kemudian mendukung Shah Reza Pahlevi yang panjang dan represif, dimana layanan keamanannya melakukan tindakan brutal terhadap warga Iran selama beberapa dekade. Selain itu, kedua negara ini juga telah bermusuhan satu sama lain sejak mahasiswa Iran mengambil alih dan menduduki Kedutaan Besar AS di Teheran pada November 1979. Hal itu mengakibatkan salah satunya, sanksi ekonomi dan terputusnya hubungan diplomatik formal antara AS-Iran.

Tensi hubungan Iran-Amerika Serikat juga sempat memanas ketika AS memihak kepada Irak. Pada September 1980, Irak berusaha menginvasi Iran. Hal ini merupakan peningkatan persaingan regional dan perbedaan agama antara kedua negara, yakni Irak yang diperintah oleh Muslim Sunni tetapi memiliki populasi mayoritas Muslim Syiah dan Iran dipimpin serta dihuni sebagian besar oleh kaum Syiah (Katzman, 2019).

Konstelasi perseteruan Iran-AS terus berlanjut. Pihak AS mendukung pemimpin Irak, Saddam Hussein, dalam perjuangannya melawan rezim Iran yang anti-Amerika Serikat. Akibatnya, AS sebagian besar menutup mata terhadap penggunaan senjata kimia oleh Irak terhadap Iran. Bahkan, beberapa pejabat AS berupaya mengubah pertentangan mereka terhadap senjata-senjata ilegal dan tidak manusiawi itu. Pihak Departemen Luar Negeri AS juga tidak ingin "bermainmain" dengan Iran untuk memicu propaganda melawan Irak. Pada tahun 1988, perang berakhir dengan jalan buntu, yakni lebih dari 500 ribu militer mati dan 100 ribu warga sipil tewas di kedua sisi. Dalam kondisi ini, Iran dan AS memiliki pilihan sulit untuk membuat keputusan di masa depan atas stabilitas regional mereka (Haass, 2005).

Hubungan Iran-AS pun semakin tegang pasca terbunuhnya Jenderal Qassem Soleimani. Pada 3 Januari 2020, atas perintah Presiden Trump, sebuah pesawat tanpa awak AS menembakkan sebuah rudal yang telah menewaskan Mayor Jenderal Qassem Soleimani, pemimpin pasukan Quds elit Iran, ketika ia tengah bersiap untuk meninggalkan bandara Baghdad (Fisher, 2020). Soleimani digambarkan oleh para analis sebagai orang paling kuat kedua di negeri Mullah setelah Pemimpin Tertinggi Iran, Ayatollah Khamenei. Maka, kematian Soleimani dianggap sebagai pemicu ketegangan konflik kedua negara tersebut. Tentu Iran tidak mau berdiam diri atas tindakan AS tersebut.

Berdasarkan data dari pihak pemerintahan Trump menyatakan bahwa Jenderal Qassem Soleimani sedang mengarahkan serangan segera terhadap aset AS di wilayah tersebut. Tetapi, para pejabat tidak mampu memberikan bukti yang jelas untuk mendukung klaim tersebut. Pasca kejadian tersebut, Iran pun merespon dengan meluncurkan rudal balistik yang menghantam dua pangkalan AS di Irak. Ketika Iran memasuki keadaan siaga tinggi, mempersiapkan kemungkinan pembalasan AS, Iran secara tidak sengaja menembak jatuh pesawat komersial Ukraina yang berangkat dari Teheran ke Kyiv. Peristiwa tersebut menewaskan 176 orang diatas pesawat (Aljazeera, 2020).

Selanjutnya, penelusuran untuk melihat pertemuan kedua negara dalam kontestasi politik global sangat penting. Dari hal tersebut untuk mengurai apa saja faktor dan akar masalah terjadinya ketegangan dan perseteruan panjang antara Iran dan AS. Dalam kaitannya perbenturan kepentingan politik, sejatinya dapat diketahui sejak meletusnya revolusi Iran. Momentum inilah yang membuat Iran sentimen anti-Amerika Serikat. Bahkan, satu-satunya negara yang menjadi ancaman dan musuh Amerika Serikat di kawasan Timur Tengah maupun pentas global.

Maka, dalam penelitian dibahas mengenai masa depan hubungan AS-Iran dan apa saja faktor yang melatarbelakangi perseteruan kedua negara ini terus berkobar dan tensi politik tinggi selama hampir 70 tahun terus terjadi. Dalam artikel ini, penulis membahas bagaimana masa depan hubungan kedua negara dengan menggunakan teori balance of power. Penelitian ini dilakukan dengan 
menggunakan studi literatur terhadap dokumen, artikel jurnal, dan sumbersumber media massa terkait kerjasama dan hubungan antara Iran-AS. Selanjutnya, penulisan artikel ini dibagi dalam beberapa bagian, yakni mengenai landasan teori balance of power, dinamika dan tantangan diplomasi Iran-Amerika Serikat, rivalitas Iran-Amerika Serikat dalam geopolitik Timur Tengah, masa depan hubungan Iran-AS dan kesimpulan.

Di dalam penelitian ini, peneliti menggunakan teoribalance of power, yakni keseimbangan kekuatan masingmasing negara. Teori ini merupakan sebuah rencana tentang usaha atau kebijakan, dimana tidak ada negara dapat memiliki posisi penguasaan dan dominasi atas yang lain. Hal ini mengindikasikan bahwa balance of power membuat negara tidak serta merta mempunyai kekuasaan dan dominasi, tetapi negara lain juga sangat mempengaruhi kekuatan dalam negeri suatu negara tersebut. Melalui teori ini, peneliti ingin menelusuri apa akar masalah dan faktor yang menjadi penyebab terjadinya ketegangan dan perseteruan antara Iran-AS. Selain itu, melihat hubungan masa depan keduanya dalam kancah politik internasional dan legitimasi yang diimplementasikan masing-masing negara dalam menjalankan kebijakan politiknya dari sisi internal maupun eksternal. Hal ini menjadi hal menarik untuk dikaji lebih dalam.

Teori balance of power berusaha menganalisa bagaimana kekuatan antar negara dalam beberapa indikator, baik dari segi militer, biaya, dan konstelasi politik. Menurut pendapat Dougherty; Pfaltzgraff, menyebutkan bahwa ada empat basis dalam perspektif balance of power, yakni negara-bangsa merupakan aktor kunci dalam system internasional, kepentingan domestik dan kebijakan luar negeri memiliki area tersendiri dari kebijakan nasional, politik internasional adalah sebuah usaha untuk kekuatan dalam lingkungan internasional yang anarkis, dan negara memiliki kemampuan untuk mencapai tujuan dan mempertahankan kepentingan. Sehingga, berdasarkan atas indikasi tersebut, masing-masing negara menakar keuntungan dan kerugian yang ditimbulkan jika melakukan perang. Maka, diplomasi atau bahkan pemutusan kerjasama antar negara menjadi konsekuensi logis yang diakibatkan atas perseteruan yang terjadi.

Jika melihat hubungan antara Iran dan Amerika Serikat dapat diketahui bahwa hubungan kedua negara tersebut mengalami kerenggangan yang terus berkepanjangan. Perbedaan kepentingan, stabilitas ekonomi, pengembangan teknologi nuklir, dan faktor-faktor lainnya menjadi penyebab terjadinya perseteruan tersebut.

\section{B. Pembahasan}

Hubungan diplomasi IranAmerika Serikat telah berlangsung sejak masa kepemimpinan Shah Reza Pahlevi. Kerjasama kedua negara sangat baik. Sebagai pemimpin tertinggi Iran, ia menjalin kerjasama dengan Amerika Serikat dibawah kontrol presiden Harry Truman.

Memang, antara Iran-AS tidak pernah melakukan adu senjata di dunia nyata. Namun tensi hubungan antara keduanya tidak pernah turun selama beberapa tahun. Pada tahun 1953, pihak AS melalui CIA berada dibalik terjadinya peristiwa kudeta yang akhirnya mengakibatkan turunnya Perdana Menteri Mohammed Mossadegh dan kembalinya kekuasaan Shah Mohammed Reza Pahlevi. Bahkan, AS sebenarnya tidak pernah menyepakati kebijakan pada masa lalu di Iran, dimana AS harus menurunkan Mossadeq dan mendukung rezim Shah Reza Pahlevi (Bill, 1981).

Selanjutnya pada tahun 1957 , AS dan Iran melakukan penandatanganan perjanjian kerja sama penggunaan nuklir untuk kepentingan sipil. Hingga pada tahun 1959, Shah Mohammed Reza Pahlevi membuka Pusat Penelitian Nuklir Tehran (McGlinchey, 2012). Di tahun 1963, Ayatollah Ruhollah Khomeini diasingkan ke Turki setelah menentang kepemimpinan Shah Mohammed Reza Pahlevi.

Pada tahun 1968, Iran juga ikut serta dalam perjanjian Nuclear Non- 
Proliferation yang mengizinkan mempunyai progam sipil sebagai usaha untuk mengganti terhadap komitmen negara tersebut melakukan pengembangan program senjata nuklir. Tahun 1977, presiden AS Jimmy Carter mengunjungi Iran dan menyebutnya negara yang relatif stabil.

Pada Januari 1979, Shah Mohammed Reza Pahlevi keluar dari Iran menuju ke Mesir. Sedangkan di bulan berikutnya, Khomeini kembali ke Iran dan menjadi pemimpin religius tertinggi. Ia juga memimpin peristiwa revolusi yang mengatur militer dan media. Atas dasar tersebut, terjadinya konflik antara Iran-AS yang belakangan ini memanas, ternyata kedua negara ini pernah menjalin kerjasama. Ketegangan antar kedua negara telah dimulai sejak kemenangan revolusi Islam Iran tahun 1979, ketika Raja Iran Mohammed Shah Reza Pahlevi yang didukung oleh pihak AS, dan akhirnya terpaksa meninggalkan negaranya akibat gejolak revolusi rakyat Iran yang memrotes berbagai kebijakan rezim monarki tersebut (Khomeini \& Algar, 1981).

Raja Mohammed Reza Pahlevi pun diganti oleh pemimpin revolusi, Ayatullah Agung Ruhollah Khomeini. Hal tersebut membuat Iran berubah menjadi negara Republik Islam Iran. Pada masa pemerintahan Raja Mohammed Reza Pahlevi, hubungan dan kerjasama Iran dan AS sangat dekat. Bagi Iran, beraliansi dengan AS memberikan perlindungan tingkat tinggi dari potensi serangan Uni Soviet. Sebaliknya, bagi pihak AS, Iran memberikan keuntungan besar karena pihak Iran mau membuka wilayahnya atas kehadiran AS dan bersedia membayar mahal keperluan militernya. Bahkan, Iran merupakan salah satu negara pengimpor senjata dari AS yang terbesar di kawasan.

Sejak saat itu, berbagai ketegangan diantara kedua negara pun terjadi. Di masa awal revolusi Iran, AS diduga berusaha melakukan sabotase dan dibalas oleh tindakan beberapa pemuda Iran. Mereka menyandera warga negara AS yang berada di Kedutaan Besar AS di Teheran selama kurang lebih 444 hari (4 November 197920 Januari 1981), (Salsabila \& Yulianti,
2019).

Akibat kasus penyanderaan tersebut, AS pun memutuskan hubungan diplomatik dengan Iran. Selain itu, pada 4 November 1979, Presiden AS Jimmy Carter juga membekukan semua harta kekayaan pemerintah Iran yang berada di wilayah hukum AS. Pihak AS pun mengembargo Iran dalam berbagai bidang, dari sektor minyak hingga sanksi pengembangan senjata.

Selanjutnya pada April 1979, pemerintah Iran resmi menjadi Republik Islam Iran. Hingga pada November 1979, Khomeini kembali melancarkan serangan dengan para pelajar menguasai kedutaan AS di Iran. Karena aksi tersebut, Presiden Carter menjatuhkan sanksi pada Iran (Phoenna; Harmiyati, 2016). Lalu, di tahun 1980, AS pun memutuskan hubungan diplomatik dengan pihak Iran. Bahkan, AS menahan aset, ekspor, dan berbagai bentuk perdagangan dengan negara tersebut. Presiden Carter memerintahkan tindakan penyelamatan dan pelepasan tahanan AS di Iran, namun usaha tersebut gagal.

Tahun demi tahun hubungan IranAS mulai terjadi tarik menarik dan melakukan kesepakatan, seperti halnya di tahun 1981, 52 orang tahanan AS dilepaskan oleh Iran pasca turunnya Carter yang digantikan Presiden Ronald Reagan. Hingga akhirnya hubungan kedua negara pada tahun 1984 menunjukkan tensi yang panas. AS memasukkan Iran dalam daftar negara yang mendukung terorisme. Pada tahun 1985-1986, Reagan pun membuka perjanjian militer rahasia dengan Teheran. Hal tersebut dinilai menodai ketentuan embargo senjata dengan negara tersebut. Hal ini pada dasarnya dilakukan untuk membebaskan tahanan di Lebanon pada perang Irak-Iran (The Reagan Administration, n.d.)

Pada tahun 1988, kapal perang AS Vincennes tidak sengaja menembak jatuh pesawat penumpang Iran yang terbang di wilayah Gulf. Insiden tersebut menewaskan 290 penumpang yang sedang dalam perjalanan. Pada tahun 1989, Ayatollah Ruhollah Khomeini meninggal dan digantikan Ayatollah Ali Kamenei. 
Saat itu Ali Akbar Hashemi Rafsanjani terpilih sebagai presiden. Selanjutnya, tahun 1992, Iran-Irak Arms Nonproliferation Act disetujui kongres yang memberi sanksi jika ditemukan teknologi atau apa saja yang berpotensi pada pengembangan senjata. Tahun 1993, presiden AS Bill Clinton menuduh Iran sebagai pendukung terorisme.

Pada tahun 1996, ia juga mengeluarkan keputusan penjatuhan sanksi pada negara asing yang berinvestasi di Iran dan Libya. Selanjutnya, pada tahun 1997, Mohammad Khatami memenangkan pemilihan Presiden Iran. Di tahun 2000, Sekretaris Negara AS, Madeleine Albright mengakui peran AS dalam kudeta tahun 1953 dan pada tahun 2002, presiden George W. Bush mendeklarasikan Iran, Irak, dan Korea Utara sebagai axis of evil. AS juga menuduh Iran memiliki program senjata nuklir rahasia (Katzman, 2003).

Di tahun 2005, Mahmoud Ahmadinejad terpilih sebagai presiden Iran. Kesepakatan demi kesepakatan kedua negara terjalin, bahkan pada tahun 2006 , AS setuju ikut dalam pembicaraan multilateral nuklir dengan Iran jika bertujuan menangguhkan program pengayaan nuklir negara tersebut.

Pada tahun 2008, kali pertama Bush mengirim utusan untuk berperan langsung dalam negosiasi nuklir dengan Iran di Jenewa. Sedangkan, di tahun 2009, AS, Inggris, dan Prancis mengumumkan penemuan lokasi pengayaan uranium rahasia di Iran. Presiden AS Barrack Obama mengatakan tidak keberatan kerja sama dengan Iran jika negara tersebut setuju.

Pada November 2013, Iran dan 5 negara anggota tetap Dewan Keamanan PBB dan Jerman atau Uni Eropa (yang disebut P5+1) melakukan penandatanganan perjanjian yang disebut Joint Plan of Action yang memberikan kelonggaran pada sebagian sanksi, termasuk didalamnya yakni pencairan dana milik Iran sebesar 4,2 miliar dollar AS yang semula dibekukan (Barzegar, 2014). Sebagai kompensasi, Iran berjanji membatasi pengayaan uranium dan mengizinkan pengawas internasional untuk masuk ke kawasan sensitif di reaktor nuklirnya.

Pada 14 Juli 2015, pasca berbagai negosiasi tingkat tinggi, AS bersama dengan negara-negara P5+1 akhirnya bersedia menandatangani Kesepakatan Nuklir JCPOA (Joint Comprehensive Plan of Actions). Di bawah kesepakatan ini, Iran berjanji membatasi program nuklirnya hingga pada level tertentu dan sebagai kompensasinya, AS dan negara-negara Barat bersedia menghentikan berbagai sanksi ekonomi terhadap Iran. Kesepakatan tersebut kemudian diadopsi menjadi Resolusi Dewan Keamanan 2231 pada tahun 2015. Meskipun demikian, JCPOA juga banyak ditentang politisi partai Republik. Bahkan ketika Donald Trump (kandidat Republikan) berkampanye, ia menjanjikan akan mengakhiri perjanjian tersebut jika menang dalam Pemilu Presiden 2016.

Donald Trump pun terpilih sebagai Presiden AS. Trump menepati janjinya dengan mengumumkan mundurnya pemerintah AS dari JCPOA pada 8 Mei 2018 dan mengancam akan menerapkan upaya sanksi ekonomi lebih keras pada Iran. Selanjutnya pada 7 Agustus 2018, pemerintahan Trump menerapkan embargo tahap pertama yang melarang beberapa perusahaan AS dalam menjalin bisnis dengan Iran di bidang aeronautika, mobil, karpet, hingga emas. Mulai November 2018, sanksi tahap kedua diterapkan berupa pembatasan kerjasama terkait bidang industri minyak dan perbankan. Dampak dari berbagai sanksi tersebut, perekonomian Iran pun mengalami penurun yang signifikan.

Manuver Trump berlanjut pada 8 April 2019 ketika ia mengumumkan bahwa militer Iran, Islamic Revolutionary Guard Corps (IRGC) dianggap sebagai organisasi teroris asing, Foreign Terrorist Organisation (FTO), (Statement from the President on the Designation of the Islamic Revolutionary Guard Corps as a Foreign Terrorist Organization | U.S. Virtual Embassy Iran, n.d.). Hal ini adalah pertama kalinya AS secara resmi menetapkan militer negara lain sebagai 
"kelompok teroris". Dengan pernyataaan bahwa kelompok IRGC adalah FTO, maka segala aliran keuangan dan perjalanan terkait dengan IRGC pun menjadi terlarang dan dikenai sanksi oleh AS.

Iran merespon manuver Trump dengan mendeklarasikan AS sebagai salah satu negara sponsor terorisme dan militer AS yang berada di kawasan Timur Tengah sebagai kelompok teroris. Pada 12 Mei 2019, empat kapal diserang di perairan Uni Emirat Arab, yakni dua kapal tanker minyak milik Saudi, Al-Marzoqah dan Amjad, kapal tanker Norwegia Andrea Victory, dan kapal tongkang Uni Emirat Arab. AS pun langsung menuduh Iran sebagai pelaku serangan tersebut. Namun Iran membantah hal tersebut. Pada hari yang sama, Pusat Komando Militer AS menyatakan bahwa sejumlah pesawat pengebom B-52 tratofortress telah dikirim ke Timur Tengah untuk menekan Iran.

Selanjutnya, pada 14 Mei terjadi serangan drone terhadap dua stasiun pengeboran minyak Arab Saudi di sebelah barat Riyadh. Pihak Houthi Yaman menyatakan bahwa pihaknya yang mengirimkan drone tersebut. Tetapi, AS dan Arab Saudi menuduh Iran berada di belakang serangan tersebut. Pada $19 \mathrm{Mei}$, sebuah roket menghantam Kedutaan Besar AS di Baghdad. Hingga kini belum diketahui secara benar siapa pengirim roket tersebut, namun AS menuduh Iran sebagai dalangnya. Selanjutnya, pada tanggal 20 Juni 2019, Iran pun menembak drone militer AS, RQ-4A Global Hawk yang melintas diatas Selat Hormuz yang merupakan teritorial Iran (Shear et al., 2019).

Dikutip dari pernyataan yang ditulis dalam akun Twitter-nya, pada 20 Juni 2019, Menteri Luar Negeri Iran, Javad Zarif, mengatakan bahwa AS telah melanggar batas wilayah Iran sehingga sudah sepatutnya Iran membela diri (What You Need to Know about the Ukrainian Plane Crash, n.d.). Komandan Pasukan Quds Garda Revolusi Iran, Mayor Jenderal Qasem Soleimani telah dibunuh Amerika Serikat di Baghdad, Irak. Iran pun meradang dan mengancam akan balas dendam. Soleimani tewas setelah kendaraan yang ditumpanginya tertembak drone militer AS di luar kompleks Bandara Internasional Baghdad pada 3 Januari 2020. Akibatnya, total 10 orang tewas akibat serangan AS yang diduga diperintahkan oleh Trump tersebut. Trump pun berdalih bahwa Jenderal Qassem Soleimani dibunuh sebagai teroris.

Tidak hanya berupaya mengancam soal balas dendam, Iran juga memutuskan untuk mengabaikan batasan pengayaan nuklir dalam perjanjian pada tahun 2015. Iran pun akhirnya benar-benar membalas serangan AS tersebut. Puluhan rudal Iran diluncurkan ke arah target pangkalan udara Ain al-Asad di Irak, yang merupakan markas tentara AS.

Berdasarkan pemaparan diatas, dapat diketahui bahwa hubungan antara AS-Iran mengalami dinamika yang fluktuatif. Berbagai faktor menyebabkan hubungan kedua negara terus bergejolak. Jika dianalisa berdasarkan teori balance of power, kekuatan dua negara memiliki amunisi yang kuat untuk saling melancarkan serangan dan balasan. Mengutip data dari Global Fire Power, jumlah militer Iran mencapai 873.000 personel (2021 Iran Military Strength, n.d.). Sedangkan, AS memiliki jumlah militer 2.260.000 personel (2021 United States Military Strength, n.d.). Perbandingan jumlah personel kedua negara tersebut mengindikasikan bahwa kekuatan militer AS lebih besar dibandingkan kekuatan militer Iran.

Selain itu, AS juga menggelontorkan dana untuk pertahanan sebesar 750 miliar dolar AS. Sementara, Iran menyediakan dana pertahanan sebanyak 19.6 miliar dolar AS. Tentu dari perbandingan dana yang dikeluarkan antara dua negara tersebut, dapat diketahui bahwa perbandingannya sangat jauh sekali dana untuk pertahanan AS dan Iran. Maka, dari data tersebut sangat tidak mungkin terjadi perang terbuka antara kedua negara. Tapi, kedua negara dapat saling berbalas, seperti halnya pasca kematian Jenderal Qassem Soleimani, pihak Iran melancarkan serangan belasan kepada AS dengan membombardir pangkalan udara Ain al-Asad di Irak, yang merupakan 
markas tentara AS di Irak. Atas berbagai perhitungan militer dan dana untuk pertahanan, maka tensi perang kedua negara hanya sebatas pertikaian senjata, tidak sampai melakukan perang darat, udara, ataupun laut, yang menyebabkan kerusakan besar di dua negara.

AS sebagai negara super power dengan kekuatan militer dan pasokan dana yang besar akan melakukan berbagai cara untuk melindungi negara dan mengeksekusi kebijakan negaranya, baik dalam negeri maupun luar negerinya. Hal ini menandakan bahwa AS akan selalu siap dan memiliki kekuatan besar untuk melakukan perang sekali pun. Apalagi Iran juga diembargo ekonomi, sehingga keadaan perekonomian Iran mengalami penurunan yang sangat parah. Untuk itu, Iran melakukan berbagai kebijakan untuk keluar dari himpitan embargo tersebut.

\section{Rivalitas Iran-Amerika Serikat dalam Geopolitik Timur Tengah}

Hubungan Iran-AS selalu menjadi perhatian penting dalam kajian hubungan internasional dan politik global. Rivalitas kedua negara dari masa ke masa mengindikasikan hubungan mereka terjadi pasang surut. Tidak hanya mengenai perimbangan kekuatan semata, tetapi hubungan AS-Iran dilatarbelakangi oleh berbagai faktor, terutama ideologi, politik dan ekonomi. AS sebagai negara adidaya telah melakukan berbagai kebijakan dan keputusan atas Iran. Seperti halnya, embargo ekonomi AS kepada Iran yang telah mengakibatkan Iran "kalang kabut" dan harus berjuang untuk menyelesaikan permasalahan tersebut.

Sejak kepemimpinan Shah Reza Pahlevi, Iran telah menjalin hubungan baik dengan AS. Kedekatan kedua negara ini telah membuat kesepakatan dan kebijakan terkait berbagai sektor penting, baik politik, ekonomi, dan lainnya.

Lambat laun hubungan Iran-AS mulai menegang. Hal ini dapat dibuktikan pada tahun 1953, pihak AS melalui agen CIA berada di balik kudeta yang mengakibatkan turunnya Perdana Menteri Mohammed Mossadegh dari kekuasaannya. Dari berbagai peristiwa yang terjadi antara Iran-AS menyebabkan kedua negara terjadi tarik menarik kepentingan.

Di lain pihak, Iran adalah satusatunya negara di kawasan Timur Tengah yang kontra dengan kebijakan AS. Bahkan, Iran selalu berusaha mengontrol dan menjadi penengah ketika terjadi konflik kawasan. Apalagi pihak pemerintah AS selalu mengintervensi negara-negara Timur Tengah. Seperti halnya invasi AS atas Irak, campur tangan AS dalam konflik Suriah, kedekatan hubungan antara AS-Arab Saudi, serta keterkaitan antara AS dengan Israel.

Jika dilihat dari segi geopolitik Timur Tengah, Iran menjadi salah satu poros penting di kawasan. Selain poros Arab Saudi yang menjadi rivalnya di kawasan. Iran sebagai negara yang menerapkan Islam dalam negaranya, membuat negara ini identik dengan karakter Islam sebagai alat politik. Tetapi, dalam hal ini Iran memiliki kebijakan luar negeri yang sangat ketat. Salah satunya yakni melawan tindakan yang semenamena dan kebijakan untuk menjaga stabilitas keamanan negaranya.

Tensi hubungan antara Iran-AS juga terus memanas di tengah pandemi Covid-19. Iran tengah diembargo ekonomi oleh AS. Sehingga Iran harus bertahan dan melakukan kebijakan krusial untuk menjaga pemerintahan dan rakyatnya dari ancaman pandemi Covid-19. Bahkan Iran adalah salah satu negara di kawasan Timur Tengah yang memiliki kasus covid-19 terbanyak, yakni mencapai 3.241.037 kasus (Iran Covid, n.d.). Kondisi ini membuat Iran harus berjuang sekuat tenaga menghadapi tantangan dan permasalahan tersebut.

Konstelasi politik Iran pasca kematian Jenderal Qassem Soleimani mengalami situasi yang sangat sulit. Apalagi Iran masih disibukkan dengan penanganan wabah Covid-19. Sementara AS juga tengah mempersiapkan persiapan Pemilu AS yang diselenggarakan tahun 2020. Maka, intensitas hubungan politik kedua negara tidak terlalu besar, jika dibandingkan sebelumnya. Tetapi Iran-AS terus berkonflik dan tensinya fluktuatif, 
melihat ancaman dan permasalahan yang tengah terjadi di kedua negara.

$$
\text { Pola hubungan Iran-AS }
$$

mengalami ketegangan dan bertambah sesuai intensitas kepentingan politik kedua negara tersebut. Apalagi Iran tengah diembargo ekonomi dari AS. Situasi sulit ini membuat Iran geram dan melakukan usaha untuk tetap survive di tengah kondisi tersebut.

Jika merunut hubungan yang terjadi antar kedua negara. Aksi-reaksi adalah kondisi yang terjadi antara dua negara tersebut. Iran tidak akan melakukan hal yang membuat AS marah, jika AS tidak memulai pertikaian yang memicu konflik. Begitu pun sebaliknya. Hal tersebut juga berlaku atas perlakuan AS kepada Rusia. Tetapi, faktanya berbagai kebijakan AS kepada Iran disebabkan atas kepentingan politik dan nasional AS. Kondisi ini membuat pertikaian dan konflik antar kedua negara akan terus terjadi seiring waktu berjalan.

Di tengah berbagai intensitas hubungan yang terjadi antar kedua negara. Pihak AS melakukan embargo kepada Iran atas beberapa kebijakan Iran yang dinilai tidak sepaham dengan AS. Berikut ini berbagai jenis embargo yang diterapkan AS terhadap Iran (Zachary, 2015), yaitu:

1. Sanksi keuangan atau perbankan, yakni upaya pelarangan terhadap lembaga yang berbasis di AS untuk melakukan berbagai transaksi keuangan dengan negara Iran, serta adanya pemberlakukan aturan "Sanksi, Pertanggungjawaban, dan Divestasi Iran Komprehensif" (CISADA), yakni lembaga keuangan negara manapun yang berurusan dengan bank Iran akan otomatis dilarang melakukan transaksi di AS atau dengan mata uang dolar AS. Selain itu, pada akhir 2011, AS mencegah importir minyak Iran melakukan pembayaran melalui bank sentral Iran. AS juga membatasi akses Iran ke mata uang asing sehingga dana dari importir minyak hanya dapat digunakan untuk perdagangan bilateral dengan negara pembeli atau untuk mengakses barang-barang kemanusiaan.

2. Sanksi ekspor minyak, yakni melarang Iran untuk melakukan ekspor minyak dan melarang perusahaan asing memberikan jasa dan investasi di Iran di bidang minyak dan gas, penjualan peralatan yang digunakan dalam penyulingan minyak, dan partisipasi dalam kegiatan yang berkaitan dengan ekspor minyak, seperti pembuatan kapal, operasi pelabuhan, dan asuransi transportasi.

3. Sanksi perdagangan, yakni AS melarang sebagian besar perusahaan AS melakukan aktivitas perdagangan atau berinvestasi di teritorial Iran. Sanksi ini dimulai pada 1995 dan dilonggarkan pada tahun 2000. Lalu pemerintahan Obama membuat pengecualian terhadap penjualan peralatan telekomunikasi.

4. Pembekuan aset dan larangan bepergian, yakni dengan melakukan upaya pembekuan aset individu dan institusi Iran, termasuk didalamnya, yakni bank, kontraktor pertahanan, dan Revolutionary Guard Corps (IRGC), serta melarang mereka berpergian ke luar negeri.

5. Sanksi pengembangan senjata, antara lain melalui adanya Undang-Undang Nonproliferasi Senjata Iran-Irak (1992). Undang-undang tersebut memberikan sanksi kepada siapapun yang membantu Teheran dalam pengembangan senjata atau perolehan "bahan kimia, biologi, nuklir, atau destabilisasi dan jenis senjata konvensional canggih".

Atas kebijakan embargo AS kepada Iran tersebut, maka Iran berupaya melakukan berbagai kebijakan untuk terlepas dari sanksi tersebut. Bahkan, embargo ekonomi juga memberikan ancaman berat terhadap Iran. Menurut data tahun 2015, Kementerian Keuangan AS memprediksi bahwa ekonomi Iran turun 15-20\% akibat sanksi dan kehilangan pendapatan minyak sebesar 160 miliar dollar AS. Selain itu, lebih dari 100 miliar dollar AS aset Iran di luar negeri juga dibekukan. Sedangkan, pada tahun 2003, AS menyerang Irak dan menggulingkan Saddam Husein, disusul seruan AS pada tahun 2004 untuk mengubah rezim di Iran dan Suriah.

Kepemilikan senjata nuklir oleh Israel juga memberikan ancaman bagi Iran, apalagi Israel juga berkali-kali memberikan ancaman serangan militer terhadap Iran. Hal tersebut memunculkan 
perasaan ketidakamanan yang serius bagi Teheran (Nuruzzaman, 2012).

Di sisi lain, atas berbagai himpitan sanksi embargo tersebut. Para elit pemerintah Iran meyakini bahwa sejarah, posisi geostrategis, sumber daya alam, dan sumber daya manusia yang dimiliki Iran adalah modal penting yang memberikan kemampuan bagi Iran untuk menjalankan peran penting dalam membentuk Timur Tengah. Mereka juga melalui catatan sejarah panjang, dimana negara-negara asing ikut campur dan mendominasi urusan dalam negeri mereka, seperti halnya Inggris, Rusia, dan AS. Faktor-faktor tersebut memberi mereka persepsi bahwa mereka harus mandiri dan berdiri di atas dua kakinya sendiri untuk melindungi wilayahnya (Tabatabai, 2019). Persepsi Iran atas dirinya sendiri akan mempengaruhi interpretasinya pada tindakan AS. Namun, meski Iran menginterpretasikan AS sebagai ancaman, kapabilitas Iran tidak memungkinkan untuk melakukan respon serupa dengan apa yang dilakukan oleh AS.

Jika melihat sejarah hubungan Iran-AS pernah terjalin erat pada masa monarki Shah Reza Pahlevi. Dengan meletusnya revolusi Islam Iran pada Februari 1979, peristiwa tersebut menandai berakhirnya kekuasaan Shah Reza Pahlevi. Hal tersebut berarti berakhir pula hubungan erat Iran-AS. Selain itu, hubungan erat antara Iran dan AS pada masa Shah Reza Pahlevi sangat berbeda sekali dengan munculnya Khomeini sebagai penguasa baru di Iran. Revolusi Iran telah menghasilkan sikap anti-Barat, khususnya AS. Hal ini berkaitan dengan besarnya dukungan pemerintah AS terhadap Shah Reza Pahlevi. Khomeini dan para pendukungnya menganggap Shah Reza Pahlevi sebagai "boneka" AS. Mereka mengidentikkan Shah Reza Pahlevi dengan AS, dan sebaliknya, AS diidentikkan dengan Shah Reza Pahlevi (Simanjuntak, 2008).

Di bawah kepemimpinan Khomeini, Iran menerapkan politik luar negeri non-Blok, atau menurut istilah mereka "la syarqiyyah, la gharbiyyah" (tidak Timur, tidak Barat). Tetapi, dalam prakteknya tindakan kebencian pemerintah Khomeini terhadap AS lebih besar daripada terhadap negara manapun (Simanjuntak, 2008). Hal ini karena begitu banyak campur tangan AS terhadap Iran.

Di lain pihak, dari kubu AS, terjadinya revolusi Iran 1979 membuat AS kehilangan kepercayaan terhadap Iran. Sejak pimpinan Revolusi Iran Imam Khomeini menjuluki pihak AS sebagai "Setan Besar", (Dabashi, n.d.). AS melakukan berbagai cara menuduh Iran sebagai penyebab memburuknya situasi keamanan di Timur Tengah, khususnya dikawasan Teluk.

Setiap terjadi tindak terorisme atau adanya partai Islam di negara tertentu, AS selalu melakukan tuduhan bahwa Iran sebagai aktor utama. AS menuduh Iran terus meluaskan pengaruh revolusinya ke negara-negara sekitar, ditandai dengan bangkitnya Hamas di Palestina, Hizbullah di Lebanon, Front Penyelamat Islam (FIS) di Aljazair, Gerakan Ennahda di Tunisia, Front Nasional Islam di Sudan, Jamaah Islam di Mesir, Partai Ishlah di Yaman dan kaum Syiah di pantai timur Arab Saudi serta Bahrain (Iran Pasca Revolusi: Fenomena Pertarungan Kubu Reformis dan Konservatif, n.d.).

Pasca wafatnya Imam Khomeini pada tahun 1989, perlawanan terhadap AS sedikit berkurang. Pemimpin baru Iran berupaya untuk mencoba membangun kembali hubungan Iran-AS. Dalam hal ini, melalui terpilihnya presiden Mohammad Khatami pada masa jabatan 1997-2005 dengan pendekatan reformis-moderat di dalam pemerintahannya. Presiden Khatami adalah presiden Iran yang moderat. Presiden dengan slogan toleransi, modernisme dan keterbukaan. Slogan inilah yang menjadi pandangan politiknya dalam kebijakan luar negerinya. Khatami berusaha menerapkan kebijakan dalam meredakan ketegangan dan mengutamakan dialog, serta kerja sama. Begitu juga hubungan Iran dengan AS. Khatami berusaha menciptakan lingkungan hubungan yang lebih baik melalui sebuah "Dialog Peradaban" dengan AS (Mohammad Khatami; 
Penerjemah, Tim CIMM; Penyunting, Sari Meutia, n.d.).

Peluang ke arah perbaikan hubungan dengan AS selalu dilakukan oleh presiden Khatami. Bahkan, dalam isu nuklir Iran yang kembali meresahkan AS. Hal ini dapat dibuktikan dengan keputusan Iran menghentikan upaya program nuklir Iran di masa Khatami. Keputusan tersebut juga menjadi nilai lebih dalam usaha perbaikan hubungan Iran-AS. Kesediaan pihak Iran untuk menunda kegiatan pengayaan uranium membuat arah perbaikan hubungan Iran-AS semakin jelas. Bahkan, dalam pertemuan di bekas istana Shah di bagian utara Teheran, Hassan Rouhani selaku Kepala Majelis Agung Keamanan Iran, ia sepakat dengan para duta besar dari Eropa untuk total menghentikan pengayaan uranium Iran. Keputusan tersebut dianggap menguntungkan Iran. Setidaknya, Iran di bawah pemerintahan Khatami dianggap sebagai negara yang mau diajak melakukan perundingan. Hal ini menjadi sinyal penting dalam proses perbaikan hubungan antara Iran dan AS yang selama ini mengalami kebuntuan dalam kerjasama.

\section{Masa Depan Hubungan Iran- Amerika Serikat}

Hubungan dan kerjasama Iran-AS belakangan ini, terutama pasca kematian Jenderal Qassem Soleimani mengalami keretakan. Bara perseteruan yang terjadi diantara kedua negara terus meningkat. Hal ini mengindikasikan bahwa hubungan IranAS berada pada puncak kekhawatiran. Jika melihat kondisi ini, maka masa depan hubungan kedua negara terus mengalami perseteruan.

Hubungan diplomatik kedua negara juga semakin suram. Hal tersebut tidak dapat dinafikan dari sejarah hubungan yang telah berjalan. Iran berusaha menjadi negara yang berdikari dan tidak terlibat hubungan dengan AS. Berbagai kebijakan yang dikeluarkan oleh pemerintah Iran membuat AS geram dan tidak terima. Bahkan, ketika Iran tengah mengembangkan nuklir. Tetapi hal itu justru membuat AS dan para negara NATO melarang tindakan tersebut.
Masa depan hubungan Iran-AS mengalami dinamika dan tantangan. Berbagai kebijakan dan peristiwa yang terjadi membuat keretakan dan perpecahan antar kedua negara. Kedepannya Iran-AS akan menjadi rival abadi. Di tengah berbagai macam kemungkinan dan kepentingan keduanya, Iran-AS seperti halnya air dan minyak yang sulit bersatu. Karena perbedaan ideologi dan kepentingan politik, sehingga hubungan Iran-AS terus memanas.

Jika merunut pada peristiwa dan hubungan Iran-AS yang terus memanas. Maka, keretakan kedua negara ini menjadi bagian dalam proses diplomasi yang tidak mudah. Jika tidak ada kesepakatan dan kebijakan dari masing-masing pemimpin negara untuk memperbaiki hubungan, maka keduanya akan terus berseteru dan saling berkonflik.

Donald Trump memahami keadaan yang sedang dialami masyarakat AS tersebut dan menjanjikan apa yang menjadi kehendak rakyat melalui slogan dalam kampanyenya, yakni, "Make America Great Again". Rakyat menyambut hangat slogan ini dan sangat berharap Trump akan membawa masyarakat AS menuju masa depan yang lebih baik.

Trump menetapkan kebijakannya sesuai dengan kepentingan AS, atas dasar slogan kampanyenya yang bertujuan untuk menjadikan AS disegani semula di pentas politik internasional. Dasar dari kebijakan Trump yakni dikenal dengan "America First". "America First" yang dimaksud Trump ialah keselamatan dan kepentingan warga AS menjadi prioritas dalam setiap kebijakan luar negerinya. Berkaitan dengan penggunaan senjata nuklir dalam apapun bentuknya sekalipun, apalagi disalahgunakan untuk tujuan yang mengarah pada persoalan stabilitas keamanan negara, maka hal itu akan mengancam negara tersebut.

Sejak Donald Trump berkuasa di AS, usaha untuk keluar dari JCPOA sangat terlihat jelas. Bahkan, Trump mengatakan bahwa JCPOA merupakan salah satu perjanjian terburuk yang pernah ditandatangani oleh pihak AS. Ia 
menyatakan; "The Iranian deal was one of the worst and most one-sided transactions the United States has ever entered into". (President Donald J. Trump Is Ending United States Participation in an Unacceptable Iran Deal - The White House, n.d.). Trump mungkin kecewa melihat Iran yang tidak akan mundur dari perjanjian ini, sementara pada masa yang sama AS harus menghentikan sanksi atas Iran jika tetap berada dalam perjanjian tersebut.

Atas dasar tersebut, maka bersikerasnya Iran dalam perjanjian JCPOA ini membawa paradigma yang positif atas negara tersebut. Perlu diketahui bahwa perjanjian nuklir Iran dalam JCPOA merupakan perjanjian bertaraf internasional yang dilegalkan oleh pihak PBB. Oleh karena itu, dalam hal ini Trump sepatutnya tidak boleh secara sepihak menarik diri dari perjanjian ini. Sebab, kondisi ini akan membuat citra buruk kepada AS.

Sekitar dua minggu sebelum Trump mengumumkan untuk menarik diri dari perjanjian nuklir Iran, yakni pada 24 April 2018, Presiden Perancis Emmanuel Macron dan Canselor Jerman Angela Merkel telah menemui Presiden Trump untuk meyakinkan Presiden AS itu untuk tetap dalam perjanjian nuklir bersama Iran dan negara-negara $\mathrm{P} 5+1$ yang lain. Ini berdasarkan sejak awal kepemimpinannya, Trump telah menunjukkan tanda bahwa AS tidak akan menandatangani perjanjian nuklir yang telah ditandatangani pada era Obama tersebut. Pada 8 Mei 2018, Trump akhirnya mengumumkan menolak dan tidak menandatangani segala perjanjian nuklir Iran (CRS Reports, n.d.). Negaranegara $\mathrm{P} 5+1$ yang lain tidak dapat mengambil keputusan dan tindakan atas AS serta memutuskan untuk tetap dalam perjanjian tersebut.

Selain itu, masyarakat internasional akan melihat AS sebagai pengkhianat perjanjian karena melanggar perjanjian yang telah ditandatanganinya sendiri. Tetapi Trump tidak peduli dengan pandangan masyarakat internasional, karena ia seorang presiden yang berpaham konservatif dan kontroversi. Maka, dalam hal ini penulis berpandangan bahwa untuk beberapa tahun yang akan datang isu nuklir Iran akan terus memanas. Selain atas dasar Trump menarik diri dari perjanjian nuklir Iran. Isu ini akan menjadi isu yang menarik dibahas oleh para pengamat dan peneliti karena konstelasi politik antara AS dan Iran terus berkecamuk dan fluktuatif.

\section{Kesimpulan}

Hubungan dan kerjasama antara satu negara dengan negara lain adalah mutlak adanya. Setiap negara memiliki kebijakan untuk menentukan mana saja negara yang harus diajak kerjasama atau tidak. Tergantung bagaimana kepentingan politik dan kesepakatan antar negara untuk menjalin hubungan. Kerjasama bilateral maupun multilateral tiap negara dengan negara lain adalah konsekuensi logis untuk membangun hubungan yang harmonis dan memberikan manfaat bagi masing-masing negara, terutama dalam kepentingan nasional negaranya.

Hubungan Iran-AS misalnya, menjadi salah satu contoh dimana hubungan antar negara tidak selamanya akan terus terjalin erat. Tetapi, adakalanya juga terjadi kerenggangan dan keretakan. Tentu hal tersebut tidak dapat dihindarkan, karena dari pihak Iran maupun AS memiliki kepentingannya masing-masing, terutama kecenderungan politik, ideologi ataupun ekonomi.

Maka, masa depan hubungan IranAS akan terus mengalami dinamika dan tantangan. Berbagai kebijakan dan peristiwa yang terjadi membuat konflik, kerenggangan dan perpecahan antar kedua negara. Kedepannya Iran-AS akan terus menjadi rival abadi. Di tengah berbagai macam kemungkinan, peluang, tantangan dan kepentingan keduanya, Iran-AS adalah dua negara yang rentan mengalami konflik. Atas nama perbedaan ideologi dan kepentingan politik, sehingga hubungan Iran-AS terus memanas.

\section{Daftar Pustaka}

2021 Iran Military Strength. (n.d.). Retrieved July 4, 2021, from https://www.globalfirepower.com 
/country-military-strength-

detail.php?country_id=iran

2021 United States Military Strength. (n.d.). Retrieved July 4, 2021, from https://www.globalfirepower.com/ country-military-strengthdetail.php?country_id=unitedstates-of-america

Ahmadinejad Menentang Amerika: Dari Nuklir Iran, Zionisme, hingga Penyangkalan Holocaust / D. Danny H. Simanjuntak; penyunting, Monang S. | OPAC Perpustakaan Nasional RI. (n.d.). Retrieved July 4, 2021, from https://opac.perpusnas.go.id/Detai 1Opac.aspx?id=248869

Barzegar, K. (2014). Iran-US Relations in the Light of the Nuclear Negotiations. The International Spectator, 49(3), 1-7.

Bill, J. A. (1981). Paved With Good Intentions: The American Experience and Iran. By Barry Rubin. (New York: Oxford University Press, 1980. Pp. xii + 426. \$17.50.). American Political Science Review, 75(3), 843-844.

CRS Reports. (n.d.). Retrieved July 4, 2021 , from https://crsreports.congress.gov/

Dabashi, H. (n.d.). Who is the 'Great Satan'? Retrieved July 4, 2021, from

https://www.aljazeera.com/opinio ns/2015/9/20/who-is-the-greatsatan

Fisher, M. (2020, January 3). Is There a Risk of Wider War With Iran? The New York Times. https://www.nytimes.com/2020/0 1/03/world/middleeast/us-iranwar.html

Haass, R. N. (2005). Regime Change and Its Limits. Foreign Affairs, 84(4), 66-78.

Iran COVID: 3,241,037 Cases and 84,627 Deaths - Worldometer. (n.d.).
Retrieved July 4, 2021, from https://www.worldometers.info/c oronavirus/country/iran/

Iran Pasca Revolusi: Fenomena Pertarungan Kubu Reformis dan Konservatif. (n.d.). Retrieved July 4, 2021, from https://catalogue.paramadina.ac.id /index.php?p=show_detail\&id $=30$ $28 \&$ keywords $=$

Katzman, K. (2003, July 25). Iran: Current Developments and U.S. Policy (Iran) [Report]. UNT Digital Library; Library of Congress. Congressional Research Service. https://digital.library.unt.edu/ark:/ 67531/metacrs4802/

Khomeini, R., \& Algar, H. (1981). Islam and Revolution: Writings and Declarations of Imam Khomeini. Mizan Press.

Membangun Dialog Antarperadaban: Harapan dan Tantangan / Mohammad Khatami; Penerjemah, Tim CIMM; Penyunting, Sari Meutia $\mid$ OPAC Perpustakaan Nasional RI. (n.d.).

Shear, M. D., Schmitt, E., Crowley, M., \& Haberman, M. (2019, June 20). Strikes on Iran Approved by Trump, Then Abruptly Pulled Back. The New York Times. https://www.nytimes.com/2019/0 $6 / 20 /$ world/middleeast/iran-usdrone.html

Simbar, R. (2006). Iran and the US: Engagement or Confrontation. Journal of International and Area Studies, 13(1), 73-87.

Statement from the President on the Designation of the Islamic Revolutionary Guard Corps as a Foreign Terrorist Organization | U.S. Virtual Embassy Iran. (n.d.). Retrieved July 4, 2021, from https://ir.usembassy.gov/statemen t-from-the-president-on-thedesignation-of-the-islamicrevolutionary-guard-corps-as-a- 
foreign-terrorist-organization/

Tabatabai, A. M. (2019). Iran's National Security Debate: Implications for Future U.S.-Iran Negotiations. https://www.rand.org/pubs/perspe ctives/PE344.html

The Reagan Administration. (n.d.). Retrieved July 4, 2021, from https://iranprimer.usip.org/resourc e/reagan-administration

What You Need to Know about the Ukrainian Plane Crash. (n.d.). Retrieved July 4, 2021, from https://www.aljazeera.com/news/ 2020/1/10/ukrainian-plane-crashin-iran-five-things-to-know 